Dinamika Sosial Budaya, Vol 22, No. 1, Juni 2020, pp 8-20

p-ISSN: 1410-9859\& e-ISSN: 2580-8524

http://journals.usm.ac.id/index.php/jdsb

\title{
DISRUPSI DARI ATAS: KASUS BANGKRUTNYA KIOS TRADISIONAL BERHADAPAN DENGAN MINIMARKET MODERN
}

\author{
Rahoyo \\ stefanus.rahoyo1970@gmail.com \\ Prodi Manajemen, Fakultas Ekonomi, Universitas Semarang \\ RR. Lulus Prapti NSS \\ Prodi Manajemen, Fakultas Ekonomi, Universitas Semarang \\ lulusprapti@usm.ac.id
}

\begin{abstract}
Various studies have concluded that the presence of modern minimarkets has a negative impact on traditional kiosks. One of the negative impacts is revenue's decrase of the tradisional kiosks. However, the various studies have not answered why and how the kiosts' revenue decrase or even they bankrupted. Losing in competition is not a correct reason to explain the above phenomenon because the fact is-and is perceived so by consumers - the price of goods in traditional kiosks is cheaper than the price of the same goods in modern minimarkets.

With a qualitative approach this study found that the phenomenon of revenue's decrease and even the bankruptcy of traditional kiosks were because of disruption and not because they could not compete with modern minimarkets. It is, however, differ from Chistensen's disruptive innovation theory where disruption always starts from low-end market; this research found the opposite direction, namely disruption starting from highend market or disruption from above.
\end{abstract}

Keywords: Alfamart, disruption, Indomaret, traditional kiosk, minimarket, competition

\begin{abstract}
Abstrak
Berbagai penelitian menyimpulkan bahwa kehadiran minimarket modern berdampak negatif terhadap kios-kios tradisional. Salah satu dampak negatif tersebut adalah menurunnya omzet. Namun, berbagai penelitian tersebut belum menjawab mengapa dan bagaimana kios-kios tradisional di atas mengalami penurunan omzet atau bahkan bangkrut. Kalah dalam persaingan bukanlah alasan yang tepat untuk menjelaskan fenomena di atas sebab faktanya - dan dipersepsikan demikian oleh konsumen - harga barang di kios tradisional lebih murah daripada harga barang yang sama di minimarket modern.

Dengan pendekatan kualitatif penelitian ini menemukan bahwa fenomena menurunnya omzet dan bahkan kebangkrutan kios-kios tradisional adalah karena terdisrupsi oleh dan bukan karena kalah bersaing dengan minimarket modern. Berbeda dengan teori disruptive innovation-nya Chistensen di mana disrupsi selalu dimulai dari pasar bawah; penelitian ini justru menemukan arah sebaliknya, yakni disrupsi dimulai dari pasar atas atau disrupsi dari atas.
\end{abstract}

Kata Kunci: Alfamart, disrupsi, Indomaret, kios tradisional, minimarket, persaingan

\section{PENDAHULUAN}


Tergerusnya pasar dan kios tradisional akibat menjamurnya minimarket dan atau ritel modern telah diungkap banyak penelitian di berbagai daerah, misalnya di Kabupaten Batubara, Kota Makassar, Kota Manado, Kota Semarang dan Kota Malang [baca: (Karim, 2018), (Mujahid \& Nurdin, 2018), (Achmad, 2015), (Aryani, 2011), (Saddewisasi, Ariefiantoro, \& Santoso, 2011)]. Semua penelitian tersebut menyimpulkan bahwa minimarket modern berdampak negatif terhadap kios-kios tradisional. Saddewisasi, misalnya, berdasarkan penelitiannya di empat kecamatan, yaitu Gunungpati, Mijen, Tembalang, dan Banyumaik menyimpulkan bahwa omzet penjualan ritel tradisional turun hingga 25\% akibat adanya minimarket (Saddewisasi, Ariefiantoro, \& Santoso, 2011); demikian juga penelitian yang dilakukan oleh Mujahid. Dengan melibatkan 80 informan, Mujahid menyimpulkan bahwa dampak dari berdirinya minimarket-minimarket modern terhadap warung kecil adalah sebagai berikut: omzet menurun, pembeli berkurang, pedagang terpaksa mengurangi item barang yang dijual, pedagang terpaksa membuka warung lebih lama, barang dagangan menjadi banyak yang kadaluwarsa (Mujahid \& Nurdin, 2018).

Namun demikian, berbagai penelitian tersebut belum mengungkap bagaimana dan mengapa kios-kios tradisional tersebut bangkrut. Apakah benar bahwa kios-kios tradisional tersebut kalah bersaing dengan minimarket-minimarket modern? Apabila ditilik dari struktur pasar, kios-kios tradisional dan minimarket-minimarket modern di atas berada dalam pasar persaingan sempurna [baca: (Gilarso, 2014), (Salvatore, 2013), (Boediono, 2008)]. Apabila harga merupakan parameter utama untuk memenangkan persaingan dalam struktur pasar yang semacam itu (Hamid, 2017), kalah dalam persaingan bukanlah alasan yang akurat untuk menjelaskan fenomena di atas sebab faktanya - atau setidak-tidaknya dipersepsikan demikian-harga suatu produk di kios tradisional lebih murah dibandingkan dengan harga produk yang sama di minimarket modern!

Pelayanan dan kenyamanan memang menjadi keunggulan lain dari minimarketminimarket modern tersebut dibandingkan dengan kios-kios tradisional. Begitupun, semua informan dalam penelitian ini mengatakan bahwa kriteria utama dan pertama mereka membeli barang di suatu tempat adalah harga dan relatif bukan pelayanan atau kenyamanan. Faktor kewirausahaan dengan karakteristik kemampuan membaca peluang, berinovasi, mengelola dan memasarkan (bukan sekadar menyediakan), keberanian mengatasi ketakutan, mengendalikan risiko dan keluar dari zona nyaman, ulet, pantang menyerah, memiliki determinasi, dan kreativitas (Rahoyo \& Niati, 2019) boleh jadi menjadi suatu penyebab; tetapi hal tersebut masih bisa diberdebatkan sangat panjang.

Daripada teori persaingan, teori inovasi disruptif (disruptive innovation) tampaknya lebih pas dan efektif untuk menjelaskan alasan kios-kios tradisional di atas bangkrut setelah menjamurnya minimarket-minimarket modern. Clayton M. Christensen sebagai pencetus teori tersebut mendefinisikan disrupsi sebagai berikut (Chistensen):

Disruptive innovations describe a process by which a product or service take root initially in simple applications at the bottom of the market and then relentlessly moves up market eventually displacing established competitors.

Christensen menekankan bahwa disrupsi pada hakikatnya adalah sebuah proses bukan produk [bdk. (Tabbah \& Maritz, 2019), (Myerson, 2019), (Brescia, 2015)]. Disrupsi merupakan suatu proses 
bagaimana suatu produk atau layanan (jasa) yang pada awalnya masuk di pasar bawah dengan basis kesederhanaan (simplicity), keterjangkauan (affordability), dan aksesibilitas (accessibility) [baca: (Rienzo \& Chen, 2018)] pada akhirnya mampu memporakporandakan dan merebut bahkan menguasai pasar yang menjadi basis pemain utama (mainstream incumbents).

Istilah disrupsi awalnya merupakan istilah yang dipakai dalam konteks bisnis, keuangan dan investasi [(Ohoitimur, 2018), (Khasali, 2017)], tetapi belakangan istilah tersebut menjadi sangat plastis dan digunakan untuk mengkaji berbagai bidang, dari industri jasa keuangan (Myerson, 2019), turisme (Crotts \& Gupta, 2013), Pendidikan [(Rienzo \& Chen, 2018), (Ohoitimur, 2018)], Perpustakaan (Hapsari, 2019), Kepemimpinan (Wulansari \& Ma'mun, 2019), Sosial (Tabbah \& Maritz, 2019), Politik (Bashori, 2018), hukum (Brescia, 2015), bahkan Seni Rupa dan Desain (Harto, 2018).

Secara ringkas disrupsi terjadi ketika incumbent (disruptee) dalam suatu industri mulai bergerak ke hulu dengan menyediakan produk atau layanan yang ada atau yang dikembangkan untuk memenuhi tuntutan sebagian besar pelanggan mereka. Pada umumnya, sebagian besar pelanggan ini sekaligus pelanggan yang sangat menguntungkan perusahaan yang memungkinkan perusahaan menghasilkan marjin keuntungan yang lebih tinggi. Incumbent mengabaikan segmen pasar tertentu lain yang umumnya adalah pasar bawah (low-end). Pengabaian tersebut dari sisi bisnis bisa dimengerti karena keuntungan dalam pasar bawah ini memang kecil (Myerson, 2019).

Pendatang baru (disruptor) melihat bahwa pasar bawah milik incumbent tidak terlindungi dan mereka masuk ke dalam pasar tersebut dengan menawarkan produk dan layanan yang memenuhi kebutuhankebutuhan spesifik para pelanggan dalam pasar tersebut. Basis utama produk dan layanan yang ditawarkan oleh pendatang baru adalah simplicity, accessibility, dan affordability. Selain berasal dari low-end market, pelanggan pendatang baru juga berasal dari pasar baru yang karena adanya inovasi teknologi memungkinkan pendatang baru mengubah non-customers menjadi customers (Tabbah \& Maritz, 2019). Hal yang perlu ditekankan adalah, para disruptor tersebut memasuki pasar sering kali dengan menawarkan business models dan value networks yang berbeda dengan incumbent pemimpin pasar (Rienzo \& Chen, 2018). Para pelanggan yang menjadi basis incumbent (high-end customers) awalnya memandang produk dan layanan yang ditawarkan oleh pendatang baru tersebut sebagai produk inferior dan kurang mampu memenuhi kebutuhan mereka [bdk. (Rienzo \& Chen, 2018)]. Atas dasar alasan "inferioritas" produk pendatang baru dibandingkan dengan produk incumbent tersebut, masuknya distruptor ke dalam pasar yang mestinya merupakan ancaman ini tidak diperhitungkan oleh incumbent.

Disruptor kemudian berusaha bergerak ke pasar atas dan menawarkan performa (performance) produk dan layanan yang sama atau setidak-tidaknya mendekati performa produk dan layanan yang ditawarkan incumbent kepada para pelanggan yang menjadi basis incumbent. Selanjutnya, para pelanggan incumbent mulai mengadopsi produk-produk atau layanan yang ditawarkan oleh pendatang baru tersebut. Apabila kinerja produk dan layanan pendatang baru mampu memenuhi kebutuhan basis utama pelanggan incumbent, pasar atas (high-end market) yang semula menjadi basis utama pemain lama atau incumbent akan beralih ke produk dan layanan yang ditawarkan pendatang baru dan pada akhirnya keseluruhan industri akan berubah (Rienzo \& Chen, 2018). Pada saat itulah disrupsi terjadi! 
Secara sederhana keseluruhan proses terjadinya disrupsi di atas bisa digambarkan dalam model sebagai berikut [Bdk. (Hamid,
2017), (Khasali, 2017), (Crotts \& Gupta, 2013)].

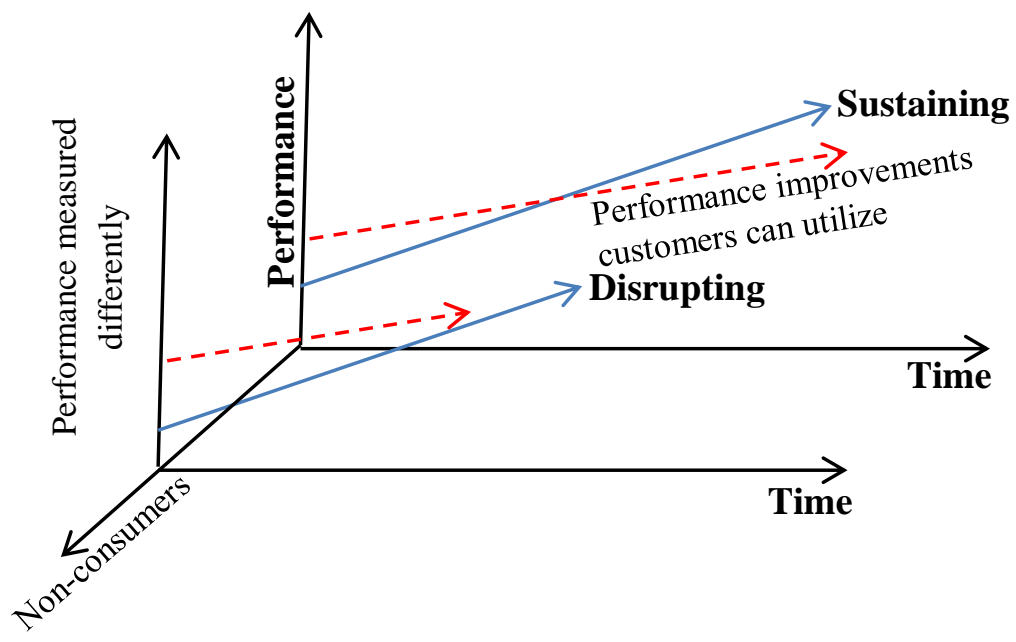

Gambar 1. Model Inovasi Disruptif Christensen (Sumber: Rienzo dan Chen, 2018)

Dengan metode kualitatif, penelitian ini bertujuan menjelaskan mengapa dan bagaimana kios-kios eceran tradisional bangkrut berhadapan dengan minimarketminimarket modern (c.q. Indomaret dan Alfamart) padahal harga barang yang sama di kios tradisional lebih murah dibandingkan dengan harga di Indomaret dan Alfamart. Teori inovasi disruptif yang dipopulerkan oleh Clayton M. Christensen menjadi alat analisis dalam penelitian ini.

\section{METODOLOGI}

Penelitian ini dilakukan dengan metode atau pendekatan kualitatif. Metode kualitatif dipilih karena peneliti ingin menggambarkan dan menjelaskan mengapa dan bagaimana kios-kios eceran tradisional bangkrut setelah hadirnya minimarket modern, khususnya Indomaret dan Alfamart. Dengan kata lain, pendekatan kualitatif dipilih karena peneliti tidak bermaksud mencari hubungan antarvariabel. Data yang diperoleh dari pendekatan kualitatif adalah kata-kata tertulis atau lisan dan perilaku yang bisa diamati (Rahoyo \& Prapti, 2019). Data tersebut diperoleh melalui metode wawancara mendalam (indept invterview), pengamatan dan studi literatur. Penggunaan metode wawancara mendalam dan pengamatan untuk mendapatkan data kualitatif ini didukung oleh pendapat Suton (2015) yang mengatakan, "What qualitative study seeks to convey is why people have thoughts and feelings that might affect the way they behave" (Suton \& Austin, 2015). Dalam hal ini, wawancara mendalam dan pengamatan merupakan cara paling efektif untuk mengeksplorasi pikiran dan perasaan orang dibandingkan dengan metode lain, misalnya survei atau kuesioner. Namun demikian, perlu dicatat bahwa penelitian kualitatif tidak dimaksudkan untuk membuat generalisasi (Suton \& Austin, 2015). Metode wawancara dan pengamatan (multi-method) digunakan sekaligus untuk menjamin konsistensi dan validitas informasi (Quick \& Hall, 2015).

Titik pangkal turunnya omzet atau bahkan bangkrutnya kios-kios ritel tradisional setelah menjamurnya Indomaret dan Alfamart adalah berkurangnya pengunjung. Oleh karena itu, data yang harus peneliti telusuri adalah mengapa para konsumen tidak (lagi) mengunjungi dan 
atau berbelanja di kios ritel tradisional. Untuk mencapai sasaran ini, peneliti mewawancarai 6 informan kunci dengan karakteristik sebagai berikut.

Tabel 1. Karakteristik Informan Kunci (Konsumen)

\begin{tabular}{clccc}
\hline NO & INFORMAN & L/P & UMUR & PEKERJAAN \\
\hline 1 & Informan 1 & $\mathrm{P}$ & 19 & Mahasiswa \\
\hline 2 & Informan 2 & $\mathrm{P}$ & 21 & Mahasiswa \\
\hline 3 & Informan 3 & $\mathrm{P}$ & 18 & Karyawan \\
\hline 4 & Informan 4 & $\mathrm{P}$ & 51 & Karyawan \\
\hline 5 & Informan 5 & $\mathrm{L}$ & 23 & PNS \\
\hline 6 & Informan 6 & $\mathrm{L}$ & 52 & Manajer \\
\hline
\end{tabular}

Sedangkan untuk mengetahui bagaimana kios-kios ritel tradisional di atas mengalami penurunan omzet; peneliti mewawancarai dan mengamati 3 informan kunci. Informan 1 adalah pemilik kios tradisional di Jl. Semarang-Boja. Berhadaphadapan dengan kios ini (di seberang jalan) terdapat Alfamart yang berdiri sekitar lima tahun lalu (2014). Informan 2: pemilik kios eceran dan grosir di Pasar Tradisional Gayamsari. Sekitar satu kilometer dari Pasar Tradisional Gayamsari berdiri sebuah pusat grosir Lottemart. Informan 3: toko atau kios tradisional Barokah di Tegalsari. Tepat di seberang jalan Kios Barokah berdiri Alfamart. Karena pemilik kios tidak bersedia diwawancarai, peneliti mewawancarai tukang parkir yang mengaku sudah lebih dari sepuluh tahun menjadi tukang parkir di Kios Barokah. Semua informan berdomisili di Kota Semarang.

\subsection{Manajemen dan Analisis Data}

Seluruh wawancara dengan informan yang berlangsung antara 20-30 menit direkam menggunakan handphone. Rekaman tersebut selanjutnya ditranskrip oleh tenaga pendukung (transkriptor). Hasil pengamatan (field notes) peneliti tambahkan ke dalam transkrip-transkrip wawancara tersebut ketika peneliti mengedit hasil transkrip wawancara yang diserahkan oleh transkriptor. Ketika mengedit hasil transkrip, peneliti sambil mendengarkan lagi rekaman hasil wawancara.
Jawaban informan yang telah ditranskrip dan dilengkapi dengan catatan lapangan dikelompok-kelompokkan berdasarkan pertanyaan yang sama. Oleh Suton, langkah ini disebut sebagai manajemen data (Suton \& Austin, 2015). Selain mengklasifikasikan (mengelompokkelompokkan) data, aspek lain dari manajemen data adalah reduksi data. Reduksi data dilakukan setelah peneliti menentukan tema-tema untuk dijadikan laporan penelitian berdasarkan jawaban informan yang telah dikelompokkelompokkan tersebut. Pada tahap ini, semua informasi yang dipandang tidak relevan dengan tema-tema yang telah ditentukan peneliti abaikan.

Berdasarkan tema-tema yang telah ditentukan di atas, peneliti melakukan analisis untuk mengetahui adakah pola-pola tertentu dari jawaban informan atas suatu tema tertentu. Misalnya, terhadap pertanyaan "Bisa diceritakan apa saja yang menjadi pertimbangan Anda memilih membeli sesuatu di suatu tempat?", semua informan menyatakan bahwa harga merupakan pertimbangan utama dan pertama. Masih mengenai harga, semua informan mengatakan bahwa harga barang di kios tradisional lebih murah dibandingkan dengan harga yang sama di Indomaret atau Alfamart, kecuali seorang informan yang menginformasikan bahwa ada kios tradisional yang menjual barang dengan harga yang lebih mahal daripada Indomaret atau Alfamart. Namun demikian, 
informasi itu pun dengan catatan bahwa si informan mengetahui bila kios tradisional tersebut mengulak barang di Indomaret atau Alfamart.

Hasil analisis merupakan temuan dari penelitian ini. Temuan tersebut kemudian didialogkan dengan referensi literatur. Dalam hal ini, peneliti membaca dan mengidentifikasi (persamaan dan perbedaan) berbagai penelitian menyangkut teori yang sama, yaitu disrupsi. Berdasarkan review literatur itulah peneliti menempatkan pada posisi mana hasil penelitian ini ditempatkan. Secara spesifik, dengan mengadopsi teori disruptive innovation-nya Clayton $\mathrm{M}$. Christensen, temuan dalam penelitian ini membuka perspektif lain dari dalil yang dikemukakan Christensen, yaitu bahwa disrupsi ternyata bisa juga terjadi dari atas.
Masifnya serbuan Indomaret dan Alfamart tidak hanya tampak kasat mata pada berdirinya kedua ritel modern tersebut yang sampai ke pelosok-pelosok kota, tetapi juga kelihatan dari pertumbuhan jumlah gerai kedua minimarket tersebut seperti tampak pada tabel 2 di bawah ini. Indomaret berdiri tahun 1988 (https://indomaret.co.id/korporat/)

sedangkan Alfamart berdiri setahun kemudian, yaitu 1989 (http://corporate.alfamartku.com/). Dalam kurun waktu 10 tahun pertama, Indomaret membangun lebih dari 3.000 gerai sedangkan Alfamart hampir 3.500 gerai. Sepuluh tahun berikutnya gerai Indomaret melonjak lebih dari empat kali lipat menjadi lebih dari 15.000 gerai sedangkan gerai Alfamart dalam kurun waktu sepuluh tahun berikutnya melonjak sekitar tiga kali lipat menjadi 13.700 gerai lebih.

\section{HASIL DAN PEMBAHASAN}

Tabel 2. Pertumbuhan Jumlah Gerai Indomaret dan Alfamart 2008 - Juli 2019

\begin{tabular}{ccccc}
\hline \multirow{2}{*}{ TAHUN } & \multicolumn{2}{c}{ INDOMARET } & \multicolumn{2}{c}{ ALFAMART } \\
\cline { 2 - 5 } & Gerai & Growth $(\%)$ & Gerai & Growth (\%) \\
\hline 2008 & 3.039 & & 2.800 & \\
\hline 2009 & 3.812 & 25,4 & 3.400 & 21,4 \\
\hline 2010 & 4.955 & 30 & 4.800 & 41,2 \\
\hline 2011 & 7.000 & 41,3 & 5.800 & 20,1 \\
\hline 2012 & 7.245 & 3,5 & 7.100 & 22,4 \\
\hline 2013 & 8.834 & 21,9 & 8.600 & 21,1 \\
\hline 2014 & 10.600 & 20 & 9.900 & 15,1 \\
\hline 2015 & 12.195 & 15 & 11.100 & 12,1 \\
\hline 2016 & 13.900 & 14 & 12.300 & 10,8 \\
\hline 2017 & 15.335 & 10 & 13.500 & 9,8 \\
\hline 2018 & 15.599 & 1,7 & 13.700 & 1,5 \\
\hline 2019 & 16.900 & 8 & 13.726 & 0,2 \\
\hline
\end{tabular}

Rahoyo \& Prapti (2019). Diolah dari berbagai sumber

Berdasarkan data pertumbuhan gerai di atas, tidak mengherankan apabila keberadaan Indomaret dan Alfamart dianggap terus menggerus pasar kios-kios tradisional. Secara lebih tajam, penelitian ini menemukan bahwa apabila kios 
tradisional diklasifikasikan ke dalam dua kelompok, yaitu (1) kios tradisional eceran dan (2) kios tradisional eceran dan atau grosir; menjamurnya Indomaret dan Alfamart secara khusus menggerus pasar kios tradisional eceran. Semua informan kunci menyatakan bahwa apabila membeli barang eceran (satuan), mereka lebih memilih ke Indomaret atau Alfamart daripada ke kios eceran tradisional sedangkan apabila membeli barang dalam jumlah banyak, mereka memilih membeli di toko tradisional (grosir). Preferensi para informan kunci ini konsisten dengan pernyataan mereka di mana semua informan menganggap dan mengatakan bahwa harga barang di kios tradisional lebih murah dibandingkan dengan harga barang yang sama di Indomaret atau Alfamart. Ini berarti bahwa menjamurnya Indomaret dan Alfamart secara langsung merebut pasar kios-kios tradisional eceran (kategori 1) padahal kios dalam kategori ini dari sisi kuantitas merupakan bagian terbesar dari seluruh kios tradisional yang ada (Baca: Saddewisasi, Ariefiantoro, \& Santoso, 2011). Sedangkan terhadap kios tradisional kategori 2 (kios tradisional grosir yang sekaligus melayani eceran), Indomaret dan Alfamart "hanya" merebut sebagian dari pasar mereka, yaitu pasar ecerannya.

Pertanyaannya adalah, apabila semua informan menyatakan bahwa harga barang di kios tradisional lebih murah daripada di Indomaret atau Alfamart dan semua informan menyatakan bahwa pertimbangan pertama dan utama mereka dalam membeli suatu barang di suatu tempat adalah harga; mengapa mereka tidak konsisten memilih berbelanja di kios tradisional? Penelitian ini menemukan, kata kunci untuk pertanyaan tersebut adalah trade-off yang worthless.

Selisih harga kalau hanya Rp700 tidak worthy. Makanya kalau beli satuan saya pilih beli di minimarket modern. Kalau

beli dalam jumlah banyak saya baru beli di kios tradisional. Kan selisihnya lumayan... Barang di minimarket modern lebih meyakinkan, tempatnya lebih bersih dan nyaman. ${ }^{1}$

Jadi, bagi informan di atas, harga barang di kios tradisional yang lebih murah hingga Rp700,00 daripada harga barang yang sama di minimarket modern kurang menarik baginya dibandingkan dengan keyakinan dan kenyamanan yang ia peroleh bila ia berbelanja di minimarket modern. Fakta ini konsisten dengan fakta lain di mana seorang konsumen rokok di kios $\mathrm{Bu}$ Mariati di Jl. Ngaliyan dan seorang konsumen rokok di Kios Barokah selalu membeli rokok di kedua kios tradisional tersebut walaupun di seberang kedua kios berdiri Alfamart. Alasan mereka tetap membeli rokok di kios tradisional milik $\mathrm{Bu}$ Mairati dan Toko Barokah adalah karena selisih harganya mencapai Rp1.500 Rp2.000 per bungkus. Apabila selisih harga Rp700 tidak menarik, tetapi angka Rp1.500 cukup menarik; berapakah angka psikologis minimum selisih harga yang mampu menarik konsumen berbelanja eceran di toko tradisional? Hal ini membutuhkan penelitian tersendiri.

Dengan demikian, jelas tergambar bahwa masalahnya bukan sekadar soal "lebih murah atau lebih mahal", melainkan sekaligus juga soal "berapa selisih harganya". Oleh karena itu, pertanyaan berikutnya adalah, mengapa di satu sisi selisih harga Rp700 tidak cukup menarik konsumen untuk membeli barang di kios tradisional dan di sisi lain, mengapa keyakinan dan kenyamanan yang diberikan minimarket modern menjadi lebih berharga daripada selisih harga Rp700 tersebut?

\subsection{Disrupsi dari Atas}

\footnotetext{
${ }^{1}$ Wawancara dengan informan tanggal 13 November 2019
} 
Rp700 menjadi relatif ketika dihadapkan dengan pendapatan dan atau pengeluaran seseorang. Pengeluaran per kapita per bulan Kota Semarang tahun 2018 adalah Rp1.771.154 (BPS, 2019). Angka Rp700 tersebut menjadi relatif sangat kecil saat ini (ketika pengeluaran per bulan Rp1,7 juta) bila dibandingkan dengan sepuluh tahun sebelumnya ketika pengeluaran per kapita per bulan Kota Semarang hanya Rp605.051 (BPS, 2016). Artinya, secara hipotetis bisa dinyatakan bahwa walaupun Rp700 saat ini tidak membuat para informan memilih berbelanja di toko tradisional, kondisi yang berbeda akan terjadi apabila selisih harga yang sama tersebut terjadi sepuluh tahun lalu. Singkat kalimat, tingkat pendapatan dan atau pengeluaranlah yang telah membuat selisih harga Rp700 tersebut menjadi kurang menarik bagi konsumen atau informan. Secara sederhana, tingkat pendapatan tersebut tercermin dalam Upah Minimum Regional (UMR) Kota Semarang, misalnya tahun 2020 sebesar Rp1.297.895 (Kompas, 2019) sedangkan sepuluh tahun lalu (tahun 2010) masih sebesar Rp961.323 (Pamungkas, 2010). Semakin tinggi penghasilan dan pengeluaran seseorang, semakin kecil nilai relatif Rp700 tersebut. Sebaliknya, semakin rendah penghasilan dan pengeluaran seseorang, semakin besar nilai relatif Rp700 tersebut.

Di sisi lain, budaya dan pendidikan telah mengubah cara pandang dan nilai seseorang. Dalam konteks penelitian ini, berbelanja tidak lagi sekadar membeli barang, tetapi juga barang yang meyakinkan (misalnya soal tanggal kadaluwarsa) di tempat yang nyaman (bersih, tertata, dingin) walaupun dengan harga yang sedikit mahal. Tentu saja hal ini sangat subjektif, tetapi pada prinsipnya adalah barang atau produk yang dibeli tidak lagi semata-mata diukur berdasarkan nilai pakai dan nilai tukarnya! Pengorbanan lebih (dalam bentuk membayar harga yang lebih mahal) bersedia dilakukan oleh konsumen untuk keyakinan dan kenyamanan yang diterimanya.

Tampaklah bahwa minimarket modern (c.q. Indomaret dan Alfamart) "menyerang" incumbent (kios-kios tradisional eceran) justru mulai dari pasar atas (high-end). Pasar itu semakin besar (yang berarti semakin menggerus pasar kios tradisional) mengikuti alur yang didalilkan Chistensen. Pertama, penetrasi pasar (dengan arah yang berlawanan dengan arah yang dikemukakan Christensen), yaitu dari pasar atas (highend) ke menengah (middle-low) dan selanjutnya ke pasar bawah (low-end). Penetrasi ini terlihat jelas dari keberadaan Indomaret dan Alfamart yang semula berpusat di tengah kota, kemudian ke pinggiran kota, dan sekarang sampai ke desa-desa. Dari sisi konsumen, semakin tingginya pendapatan, pendidikan dan kesadaran (perubahan sosial) sebagaimana telah disinggung di atas tentu saja sekaligus mempermudah penetrasi pasar oleh Indomaret dan Alfamart. Kedua, penciptaan pasar dengan menciptakan konsumen baru. Sebagaimana dikemukakan Christensen, penciptaan konsumen baru ini dimungkinkan karena adanya inovasi teknologi. Dalam kasus perluasan pasar Indomaret dan Alfamart, hal itu dengan mudah bisa dibuktikan dengan, misalnya, karena inovasi teknologi telah memungkinkan transaksi on-line, konsumen bisa membayar pembelian apa pun dari penjual mana pun dan bahkan menarik uang tunai di Indomaret dan Alfamart. Tentu saja, konsumen baru ini pun bisa terbentuk secara alamiah, yaitu dengan semakin banyaknya lulusan yang kemudian bekerja (berpenghasilan).

Karena "menyerang" dari pasar atas, produk tetapi terutama layanan yang diberikan oleh Indomaret dan Alfamart pun lebih superior dibandingkan dengan produk dan layanan yang diberikan oleh kios tradisional. Produk yang dijual di minimarket modern dan di kios tradisional 
bisa saja sama, memiliki nilai pakai dan nilai tukar yang sama tetapi jaminan akan kualitas diberikan oleh minimarket modern. Apakah jaminan ini benar-benar fakta atau sekadar persepsi para informan, itu soal lain. Yang penting adalah, superioritas produk dan layanan yang diberikan Indomaret dan Alfamart memberikan nuansa yang bertolak belakang dengan perspektif Teori Disrupsi-nya Christensen. Karena disrupsi-menurut Christensenselalu dimulai dari pasar bawah (low-end), produk dan layanan yang ditawarkan oleh disruptor pun pada awalnya merupakan produk dan layanan yang dipandang inferior oleh basis utama konsumen mainstream incumbent (Chistensen). Fakta sebaliknya terjadi: dalam kasus kios tradisional yang terdisrupsi oleh minimarket modern, produk tetapi terutama layanan yang ditawarkan oleh disruptor (Indomaret dan Alfamart) adalah produk dan layanan yang superior.

\subsection{Inovasi}

Dalam perkembangannya, Indomaret dan Alfamart yang awalnya merupakan toko kelontong belakangan juga menyediakan layanan Anjungan Tunai Mandiri (ATM), pembayaran listrik, pembelian tiket kereta atau pesawat, pembayaran booking hotel, pembayaran transaksi on-line, top up e-money, dsb. Selain jaringan ribuan Indomaret-Alfamart yang tersebar di seluruh pelosok Indonesia mustahil eksis tanpa dukungan inovasi teknologi, semua inovasi produk dan layanan oleh Indomaret dan Alfamart tersebut juga jelas bertumpu pada inovasi teknologi. Di sinilah inovasi teknologi berperan sebagai penggerak utama disrupsi [Baca: (Rienzo \& Chen, 2018), (Ohoitimur, 2018), (Tabbah \& Maritz, 2019), (Brescia, 2015)]. Sementara itu, kios-kios tradisional ritel sebagai incumbent stagnan tanpa inovasi dalam hal produk dan layanan atau bahkan merosot sebagaimana diceritakan oleh seorang informan sebagai berikut.

Dulu orang-orang membayar
listrik, PAM atau telepon di
sini. Saya juga melayani jasa
fotokopi. Tapi, setelah di depan
itu berdiri Alfamart; listrik,
PAM dan lain-lain itu dialihkan
ke sana kecuali saya bisa
menyediakan deposit
Rp25.000.000... Persediaan
barang juga saya kurangi...
jual yang pasti laku-laku saja.

Menurut informan, selain berjualan kelontong, kios miliknya dulu juga melayani pembayaran listrik, PAM, telepon dan foto kopi. Semua layanan (listrik, PAM dan telepon) dihentikan setelah dialihkan ke Alfamart yang berdiri di seberang kiosnya karena ia tidak mampu menyediakan uang deposit sebesar Rp25.000.000. Selain itu, ia kini hanya menyediakan barang-barang yang pasti laku. Barang-barang slow moving apalagi dead stock tidak lagi ia stok.

Fakta itu menunjukkan bahwa produk dan layanan yang diberikan oleh kios tradisional tersebut justru merosot di tengah gempuran produk dan layanan yang semakin banyak dan variatif yang diberikan oleh minimarket modern. Fakta ini juga membuka perspektif yang berbeda dari kasus disrupsi yang dicontohkan Christensen. Dalam teorinya, Christensen menyebutkan bahwa incumbent sesungguhnya bukan tidak melakukan inovasi. Ia justru terus-menerus melakukan inovasi (sustaining innovation) memperbaiki produknya agar produk tersebut memenuhi tuntutan sebagian besar customers-nya. Contoh dalam hal ini, misalnya, taksi Bluebird (Baca: Khasali, 2017). Sebagai incumbent dalam industri angkutan, Bluebird terus berinovasi (dengan pengadaan armada-armada baru

\footnotetext{
${ }^{2}$ Wawancara dengan informan kunci, tanggal 18 Desember 2019.
} 
bahkan armada-armada kelas premium). Demikian juga Nokia, ia terus-menerus melakukan inovasi. Tetapi, pada akhirnya Bluebird terdisrupsi oleh Grab yang sama sekali tidak memiliki armada taksi dan Nokia terdisrupsi oleh Android yang awalnya sama sekali tidak diperhitungkan oleh Nokia. Hal ini berbeda dengan kasus Indomaret dan Alfamart di mana kios-kios tradisional cenderung stagnan dalam hal inovasi bahkan merosot.

Oleh karena itu, dalam kasus bangkrutnya kios-kios tradisional akibat terdisrupsi oleh minimarket modern Indomaret dan Alfamart, model disruptive innovation sebagaimana diadaptasi oleh Rienzo (2018) harus dimodifikasi menjadi sebagai berikut.

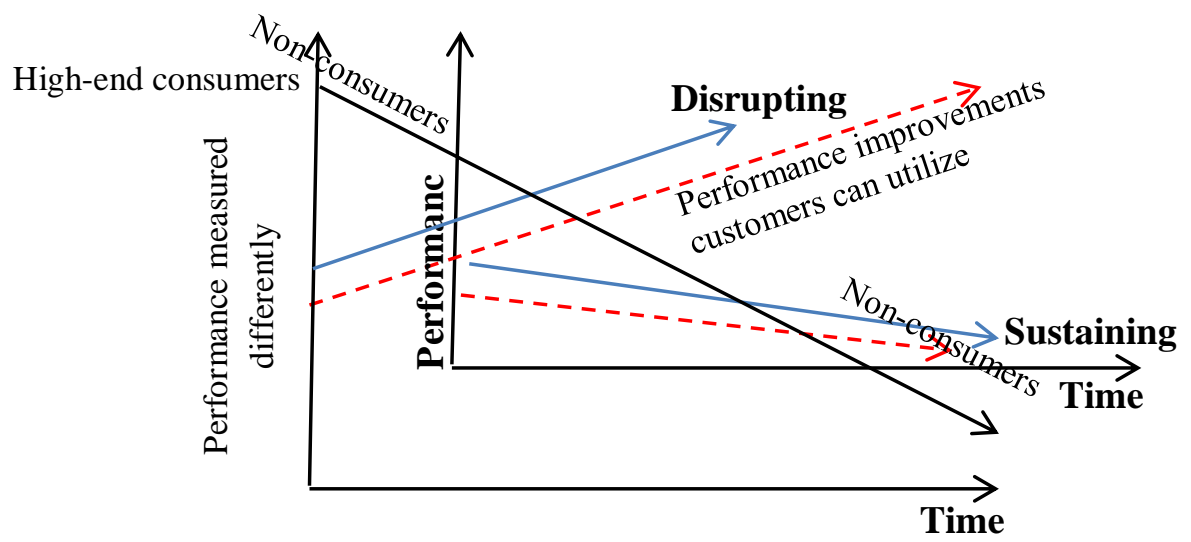

Gambar 2. Disrupsi yang Terjadi pada Kios Tradisional (Rahoyo, Prapti, 2020. Diadaptasi dari gambar Rienzo dan Chen, 2018.)

Secara ringkas, persamaan dan perbedaan disruptive innovation model Christensen dengan disruptive innovation

yang terjadi pada kasus kios tradisional eceran terangkum dalam tabel berikut ini.

Tabel 2. Perbandingan Disruptive Innovation Model Christensen dan Disrupsi yang Terjadi pada Kasus Kios Tradisional

\section{Disruptive Innovation Model Christensen}

Selalu dimulai dari pasar bawah (low-end market) dengan produk yang awalnya dipandang inferior.

Disruptee terus-menerus melakukan inovasi (sustaining innovation) agar performance perusahaan memenuhi tuntutan basis pasar utama.

Incumbent merupakan perusahaan besar, mapan dan pada umumnya pemimpin pasar (market leader)

Teknologi menjadi pendorong utama terjadinya disrupsi.

\section{Disruptive Innovation Kasus Kios Tradisional}

Dimulai dari pasar atas (high-end market) dengan produk dan terutama layanan yang superior.

Disruptee hampir tidak melakukan inovasi atau bahkan mengurangi performance.

Incumbent sebagian besar merupakan usaha kecilkecilan.

Teknologi menjadi pendorong utama terjadinya disrupsi

Bertitik tolak dari pertanyaan: mengapa perusahaan-perusahaan besar bahkan pemimpin pasar bisa dikalahkan oleh perusahaan kecil padahal perusahaan kecil tersebut kalah dalam hal dana dan sumber daya (Jurnal Komunikasi Indonesia)
Bertolak dari pertanyaan: mengapa kios-kios tradisional eceran bangkrut berhadapan dengan Indomaret dan Alfamart. 


\section{KESIMPULAN}

Orang pada umumnya menganggap bahwa kios-kios tradisional bangkrut karena kalah bersaing dengan minimarket modern, khususnya Indomaret dan Alfamart. Namun demikian, penelitian ini menemukan bahwa fenomena bangkrutnya kios-kios tradisional tersebut pertama-tama bukan persoalan kalah bersaing melainkan karena terdisrupsi oleh keberadaan Indomaret dan Alfamart. Akan tetapi, berbeda dengan disrupsi model Clayton $\mathrm{M}$. Christensen di mana disrupsi selalu dimulai dari pasar bawah (low-end market), penelitian ini menemukan sebaliknya bahwa pada kasus bangkrutnya kios tradisional berhadapan dengan Indomaret dan Alfamart, disrupsi tersebut dimulai dari pasar atas (high-end market). Dengan demikian, penelitian ini sekaligus memperkaya dan membuka perspektif lain mengenai teori disrupsi yang selama ini dipahami.

Namun demikian, penelitian ini belum menyertakan klasifikasi yang tegas antara pasar atas, menengah, dan bawah. Terbuka kemungkinan, setelah diklasifikasikan dengan tegas secara kuantitatif untuk membedakan ketiga lapisan pasar tersebut; disrupsi justru terjadi mulai dari pasar tengah kemudian bergerak menuju ke dua arah, yaitu pasar atas dan pasar bawah. Penelitian lebih lanjut perlu dilakukan untuk menguji kemungkinan ini. Penelitian ini juga belum mengkaji lebih dalam mengenai seberapa signifikan pengaruh semakin tingginya tingkat pendapatan konsumen terhadap preferensi konsumen memilih Indomaret dan Alfamart sebagai tempat berbelanja daripada kios tradisional.

\section{PENGHARGAAN}

Penghargaan pertama-tama diberikan kepada para informan kunci yang telah bersedia memberikan informasi untuk tercapainya tujuan penelitian ini. Mereka adalah Ita, Saraswati, Intan Nabila, Ida,
Dwi Novianto dan Bambang sebagai konsumen; Rosiana, Mariati dan Bapak X tukang parkir di Toko Barokah. Dari ketiga informan kunci ini peneliti memperoleh informasi dari sudut pandang pemilik kios.

Penghargaan selanjutnya diberikan kepada Lembaga Penelitian dan Pengabdian kepada Masyarakat Universitas Semarang yang telah mendanai penelitian ini.

\section{REFERENSI}

Achmad, S. (2015). The Impact of Indomaret Operated on Traditional Small Kiosks' Sales in Manado City. Jurnal Emba Vol. 3 No. 3, 130-136.

Aryani, D. (2011). Efek Pendapatan Pedagang Tradisional dari Ramainya Kemunculan Minimarket di Kota Malang. Jurnal Dinamika Manajemen.

Bashori, K. (2018). Pendidikan Politik di Era Disrupsi. Jurnal Pendidikan Sukma Vol. 2 No. 2.

Boediono. (2008). Ekonomi Mikro. Yogyakarta: BPFE.

BPS. (2016). Retrieved Januari 28, 2020, from Badan Pusat Statistik Kota Semarang: https://semarangkota.bps.go.id/subj ect/5/konsumsi-danpengeluaran.html

BPS. (2019). Retrieved Januari 28, 2020 , from Badan Pusat Statistik Provinsi Jawa Tengah: https://jateng.bps.go.id/statictable/2 019/10/14/1705/rata-ratapengeluaran-per-kapita-sebulanmakanan-dan-bukan-makanan-didaerah-perkotaan-dan-perdesaanmenurut-kabupaten-kota-diprovinsi-jawa-tengah-rupiah-2018.html 
Brescia, R. H. (2015). Embracing

Disruption: How Technological

Change in the Delivery of Legal

Services Can Improve Access to

Justice. Albany Law Review Vol. 78

No. 2.

Chistensen, C. M. (n.d.). Retrieved

January 2, 2020, from

www.claytonchristensen.com.

Crotts, J. C., \& Gupta, S. (2013).

Innovation and Competitiveness:

What We Can Learn from Clayton

Christensen. Journal of Tourism

Vo. 14 No. 1.

Gilarso, T. (2014). Pengantar Ilmu

Ekonomi Mikro. Yogyakarta: PT

Kanisius.

Hamid, E. S. (2017). Retrieved 1 21, 2020, from Law.UII.ac.id.

Hapsari, D. (2019). Tantangan

Perpustakaan Perguruan Tinggi di

Era Disrupsi. Pustakaloka Vol. 11 No. 1.

Harto, D. B. (2018). Memosisikan Bahasa Rupa VT sebagai Pisau Analisis dan Konsep Berkarya dalam Bidang Seni Rupa dan Desain di Era Disrupsi. Sendi_U.

Indonesia, J. K. (n.d.). Retrieved January 10, 2020, from Jurnal Komunikasi Indonesia.UI.ac.id.

Karim, M. S. (2018). Analisis Dampak Keberadaan Ritel Modern (Minimarket) terhadap Pedagang Kelontong di Kecamatan Tanjung Tiram, Kabupaten Baturara, Sumatera Utara.

Khasali, R. (2017). Disruption. Jakarta: PT. Gramedia Pustaka Utama.

Kompas. (2019, November 21). Retrieved January 31, 2020, from www.Kompas.com: https://www.kompas.com/tren/read /2019/11/21/121708165/rincianumk-jawa-tengah-2020-tertinggirp-27-juta-terendah-rp-17juta?page $=$ all

Masyhuri, M., \& Utomo, S. W. (2017). Analisis Dampak Keberadaan Pasar Modern terhadap Pasar Tradisional Sleko di Kota Madiun. Jurnal Akuntansi dan Pendidikan Vol. 6 No. 1, 59-72.

Mujahid, \& Nurdin, N. (2018). DAMPAK KEBERADAAN MINIMARKET TERHADAP WARUNG KECIL DI KOTA MAKASSAR . Jurnal Sinar Manajemen Vol. 5 No. 1, 1-8.

Myerson, D. (2019). The Next Global Disruptive Innovation: Can Mobile Money Make the Journey Upmarket to Disrupt the Financial Services Industry? Northwestern Journal of International Law and Business Vol. 39 No. 3.

Ohoitimur, J. (2018). Disrupsi: Tantangan bagi Perkembangan Ilmu Pengetahuan dan Peluang bagi Lembaga Pendidikan Tinggi. Jurnal Respons Vol. 23 No. 2.

Pamungkas, S. (2010, November 25). Retrieved January 31, 2020, from Setyo Pamungkas: https://setyopamungkas.wordpress. com/2010/11/25/besaran-umkjateng-sk-gubernur-jawa-tengahnomor-561-4692010/

Quick, J., \& Hall, S. (2015). Part two: Qualitative Research. United Kingdom: The Association for Perioperative Practice.

Rahoyo, \& Niati, A. (2019).

Entrepreneurial Bureaucracy:

Sebuah Tuntutan Mutlak untuk Menutup Capacity Gap Aparatur Birokrasi dalam Era Otonomi 
Dinamika Sosial Budaya, Vol 22, No. 1, Juni 2020, pp 8-20

p-ISSN: 1410-9859\& e-ISSN: 2580-8524

http://journals.usm.ac.id/index.php/jdsb

Daerah. Jurnal Solusi Vol. 17 No. 1, 83-93.

Rahoyo, \& Prapti, R. (2019). Bank Keliling Pemburu Rente dan Involusi Usaha Pedagang Pasar. Jurnal Solusi Vol. 17 No.4.

Rienzo, T., \& Chen, K. (2018). Planning for Low End Analytical Disruptions in Business School Curricula. Journal of Innovative Education Vol. 16 No. 1.

Saddewisasi, W., Ariefiantoro, T., \& Santoso, A. (2011). Analisis Dampak Usaha Ritel Modern terhadap Usaha Ritel Tradisional (Studi Kasus di Wilayah Kecamatan Gunungpati, Mijen, Tembalang, dan Banyumanik). Riptek Vol. 5 No. 1, 31-43.

Salvatore, D. (2013). Mikroekonomi (Edisi $I V)$. Jakarta: Penerbit Salemba.

Sihombing, E., \& Hidayat, P. (2013). Analisis Dampak Kehadiran Ritel Modern terhadap Ritel Tradisional di Kota Medan. Jurnal Ekonomi dan Keuangan Vol. 1 No. 4.
Suton, J., \& Austin, Z. (2015). Qualitative Research: Data Collection, Analysis, and Management. CJHP Vol. 68 No. 3.

Tabbah, R., \& Maritz, A. (2019). Demystifying Disruptive Innovation Phenomenon: Economic and Societal Impact. Revista de Cercetare si Inteventie Sociala Vol. 64.

Utomo, T. J. (2011). Persaingan Bisnis Ritel: Tradisional vs Modern. Fokus Ekonomi Vol. 6 No. 1, 122133.

Wulansari, A., \& Ma'mun, A. A. (2019). Karakteristik Kepemimpinan dalam Dunia Pendidikan untuk Merespons Era Disrupsi. Manageria Vol. 4 No. 2.

http://corporate.alfamartku.com diakses 31 Januari 2020

https://indomaret.co.id/korporat diakses 31 Januari 2020. 